\title{
Antiviral Effect of Hyunggaeyungyo-Tang on A549 Cells Infected with Human Coronavirus
}

\author{
Seo-Young Won $\mathbb{D}^{1,2}$ In-Chan Seol $\mathbb{D}^{1,3}$ Ho-Ryong Yoo $\mathbb{D}^{1,3}$ and Yoon-Sik Kim $\mathbb{D}^{1,2}$ \\ ${ }^{1}$ Department of Korean Internal Medicine, College of Korean Medicine Daejeon University, Daejeon KS015, Republic of Korea \\ ${ }^{2}$ Department of Korean Internal Medicine, Cheonan Korean Medicine Hospital of Daejeon University, \\ Cheonan-Si KSO02, Republic of Korea \\ ${ }^{3}$ Department of Korean Internal Medicine, Daejeon Korean Medicine Hospital of Daejeon University, \\ Daejeon KS015, Republic of Korea
}

Correspondence should be addressed to Yoon-Sik Kim; yoonsik@dju.kr

Received 17 May 2021; Revised 8 July 2021; Accepted 30 August 2021; Published 6 October 2021

Academic Editor: Yu Hsiang Kuan

Copyright (C) 2021 Seo-Young Won et al. This is an open access article distributed under the Creative Commons Attribution License, which permits unrestricted use, distribution, and reproduction in any medium, provided the original work is properly cited.

\begin{abstract}
Background. Herbal medicine is widely recommended to treat viral infectious diseases. Over 123,000,000 individuals have been infected with the coronavirus since a worldwide pandemic was declared in March 2020. We conducted this research to confirm the potential of herbal medicine as a treatment for coronavirus. Methods. We infected the A549 cell line with betacoronavirus OC43 and then treated it with $100 \mu \mathrm{g} / \mathrm{mL}$ Hyunggaeyungyo-tang (HGYGT) or distilled water with a control of HGYGT. We measured the mRNA expression levels of proinflammatory cytokines and interferon stimulated genes (ISGs) to confirm the effectiveness of HGYGT upon coronavirus infection. Results. We found that the effects of HYGYT decrease the expression level of pPKR, peIF2 $\alpha$, IFI6, IFI44, IFI44L, IFI27, IRF7, OASL, and ISG15 when administered to cells with coronavirus infection. The expressions of IL-1, TNF- $\alpha$, COX-2, NF- $\kappa$ B, iNOS, and IKK mRNA were also significantly decreased in the HGYGT group than in the control group. Conclusion. Through the reduction of the amount of coronavirus RNA, our research indicates that HGYGT has antiviral effects. The reduction of IKK and iNOS mRNA levels indicate that HGYGT reduces coronavirus RNA expression and may inhibit the replication of coronavirus by acting on NF-kB/Rel pathways to protect oxidative injury. In addition, decreases in mRNA expression levels of proinflammatory cytokines indicate that the HGYGT may relieve the symptoms of coronavirus infections.
\end{abstract}

\section{Introduction}

The number of infectious diseases caused by coronaviruses has recently increased. The severe acute respiratory syndrome coronavirus 1 (SARS-CoV-1) led to a pandemic in 2002, the Middle East respiratory syndrome (MERS)-CoV in 2012, and the SARS-CoV-2 in 2019. Coronaviruses are divided into four types: alpha, beta, gamma, and delta. Human $\mathrm{CoV}(\mathrm{HCoV})$ belongs to the genera Alphacoronavirus and Betacoronavirus. Types 229E and NL63 are Alphacoronaviruses. OC43, HKU1, SAR-CoV-1, MER-CoV, and SAR-CoV-2 are Betacoronaviruses. A novel CoV (2019$\mathrm{nCoV}$; SAR-CoV-2), identified in January 2020, resulted in respiratory symptoms and had spread worldwide. The recent coronavirus infection, named coronavirus disease 2019
(COVID-19) by the World Health Organization, has led to a global pandemic.

The COVID-19 Korean Medicine Treatment Recommendation, written based on the National Health Commission of the People's Republic of China's treatment plan, recommends herbal medicine treatment at the appropriate time. Some guidelines recommend that uninsured herbal extracts are administered for symptomatic relief. However, in Korea, uninsured herbal extracts are generally perceived to be ineffective compared with packed herbal medicines. Therefore, we determined the effectiveness of an uninsured herbal extract for the treatment of COVID-19.

Hyunggaeyungyo-tang (HGYGT) is an herbal medicine composed of 13 herbs (Table 1). HGYGT is widely 
TABle 1: Composition of HGYGT.

\begin{tabular}{lc}
\hline Scientific name & Amount (g) \\
\hline Schizonepeta tenuifolia Briquet (KP) & 0.5 \\
Scutellaria baicalensis Georgi (KP) & 0.5 \\
Saposhnikovia divaricata Schischkin (KP) & 0.5 \\
Angelica gigas Nakai (KP) & 0.5 \\
Poncirus trifoliata Rafinesque (KP) & 0.5 \\
Paeonia lactiflora Pallas (KP) & 0.5 \\
Glycyrrhiza uralensis Fischer (KP) & 0.5 \\
Cnidium officinale Makino (KP) & 0.5 \\
Angelica dahurica Bentham et Hooker f (KP) & 0.83 \\
Gardenia jasminoides Ellis (KP) & 0.5 \\
Platycodon grandiflorum A. De Candolle (KP) & 0.83 \\
Forsythia suspensa Vahl (KP) & 0.5 \\
Bupleurum falcatum Linné (KP) & 0.83 \\
\hline
\end{tabular}

HGYGT: Hyunggaeyungyo-tang; KP: Korean Pharmacopeia.

prescribed in patients with anhidrosis, excessive thirst, excessive sputum, fever, or sore throat. It has been reported that $88 \%$ of patients with COVID-19 had fever, $65 \%$ had dyspnea, and $60 \%$ had a cough [1]. HGYGT is prescribed for these symptoms. We confirmed the antiviral effect of HGYGT using a cell line infected with OC43, a relatively safe Betacoronavirus.

Protein kinase RNA-activated (PKR) is one of four mammalian serine-threonine kinases that primarily react to double-stranded RNA (dsRNA) during a viral infection and phosphorylate the eukaryotic initiation factor $2 \alpha$ $(\mathrm{eIF} 2 \alpha)$ translation initiator. The phosphorylation of eIF $2 \alpha$ inhibits the translation of viral mRNAs, ceasing viral replication [2]. In addition, dsRNA is a potent inducer of type I IFN, which produces interferon stimulated genes (ISGs) and forms a protective antiviral state [3]. Virus infection produces reactive oxygen specifications (ROS), which causes virus replication and oxidative injury. [4] We identified the presence of immune-related proteins such as PKR, phosphorylated PKR(pPKR), eIF2, and phosphorylated eIF $2 \alpha$ (peIF $2 \alpha$ ) using immunocytochemistry and measured the expression of proinflammatory cytokines and ISGs to confirm and understand the antiviral effects of HGYGT in A549 cells infected with human coronaviruses.

\section{Materials and Methods}

2.1. Reagents and Instruments. The HGYGT used in this experiment was purchased from Hanpoong Pharm. (Jeonju, Korea). The amount of HGYGT's validity was calculated to control the concentration of the active ingredient. HGYGT was diluted with physiological saline to $100 \mu \mathrm{g} / \mathrm{mL}$.

The reagents used are TRIsure (Bioline, England), SYBR (Bioline, England), reverse transcriptase (Thermo Fisher Scientific, USA), dNTP (Takara, Japan), DNase (Takara, Japan), RNase inhibitor (Takara, Japan), protease inhibitor (Takara, Japan), primary antibody (Cell Signaling Technology, USA), secondary antibody (Thermo Fisher Scientific, USA), sodium acetate (Invitrogen, USA), and ethanol (Sigma, Germany).
The devices used are RT-PCR (Thermo Fisher Scientific, USA), microreader (Thermo Fisher Scientific, USA), PCR machine (Thermo Fisher Scientific, USA), and ChemiDoc (Thermo Fisher Scientific, USA).

2.2. Cell Culture. A549 cells (Korean Cell Line Bank, Korea) were cultured in RPMI medium (Welgene, Korea) and 10\% fetal bovine growth serum (RMbio, USA). The cells were cultured at $37^{\circ} \mathrm{C}$ in a humidified atmosphere containing $5 \%$ $\mathrm{CO}_{2}$.

2.3. Virus Infection. OC43 (1.0 MOI) was added to $5 \times 10^{5}$ A549 cells, and the cells were incubated for three days. Cells were then treated with HGYGT $(100 \mu \mathrm{g} / \mathrm{mL})$ or deionized, distilled water (DW). The cells were cultured for $72 \mathrm{~h}$ prior to RNA extraction.

2.4. SRB Viability Assay. Two days after drug treatment, the cells were fixed during $1 \mathrm{hr}$ with 10\% TCA solution, washed twice with DPBS, and dried at room temperature. The cells were stained with a $0.05 \%$ SRB solution. The stained cells were washed four times with $1 \%$ acetic acid and dried at room temperature. After washing four times with DPBS, the cells were then reconstituted $1 \mathrm{hr}$ at room temperature using $10 \mathrm{mM}$ Tris $(\mathrm{pH}=10.5)$. The supernatant of Tris washed samples are analyzed with a microplate reader at an absorbance of $510 \mathrm{~nm}$.

2.5. RNA Extraction. The total RNA was extracted using TRIsure (Bioline, England). Prepared cells were distributed into an 8 pi medium consisting of $1 \times 10^{6}$ cells on 100 pi plates. A549-OC43 cells (OC43 group) and A549-OC43 cells treated with HGYGT (HGYGT group) were cultured for $72 \mathrm{~h}$. All prepared groups were incubated for $5 \mathrm{~min}$ at room temperature before treatment with $1 \mathrm{~mL}$ of TRIsure per $5 \times 10^{5}$ cells. The lysate was passed several times with a pipette tip. After incubation for $5 \mathrm{~min}$ at room temperature, chloroform was added, and the mixture was vortexed for $15 \mathrm{~min}$ and then centrifuged for $1 \mathrm{~h}$ at $15,000 \mathrm{rpm}$. After the supernatant was discarded, the pellet was blended with cold isopropyl alcohol to precipitate the RNA. The sample was incubated at room temperature for $10 \mathrm{~min}$ and centrifuged at $12,000 \mathrm{rpm}$ at $4^{\circ} \mathrm{C}$ for $10 \mathrm{~min}$. The pellet was washed using $75 \%$ ethanol, air-dried, and dissolved in PCR water. To remove the genetic DNA, purified nucleic acids were treated with DNA enzyme I (Takara, Japan). RNA was reversetranscribed using RevertAid reverse transcriptase (Thermo Fisher Scientific, USA). The sample was centrifuged for $10 \mathrm{~min}$ at $12,000 \mathrm{rpm}$ and room temperature, and the supernatant was discarded. After it was washed twice with $75 \%$ ethanol and dried, the pellet was dissolved in DW.

2.6. cDNA Synthesis and RT-PCR. For reverse transcription (RT) reactions, PCR was performed with $800 \mathrm{ng}$ of total RNA prepared with $1 \mu \mathrm{L}$ of random primer. The sample was denatured at $65^{\circ} \mathrm{C}$ for $5 \mathrm{~min}$, and then, the temperature 
dropped to $4^{\circ} \mathrm{C}$ before $4 \mu \mathrm{L}$ of a $10 \mathrm{mM}$ dNTP mixture and $1 \mu \mathrm{L}$ of reverse transcriptase were added with $1 \mu \mathrm{L}$ RNase inhibitor $(20 \mathrm{U} / \mu \mathrm{L})$ and $4 \mu \mathrm{L} 5 \times \mathrm{RT}$ buffer $(250 \mathrm{mM}$ Tris$\mathrm{HCl}, \mathrm{pH}=8.3,375 \mathrm{mM} \mathrm{KCl}$, and $15 \mathrm{mM} \mathrm{MgCl}_{2}$ ). PCR was performed at $25^{\circ} \mathrm{C}$ for $10 \mathrm{~min}$, at $42.5^{\circ} \mathrm{C}$ for $60 \mathrm{~min}$, and at $70^{\circ} \mathrm{C}$ for $10 \mathrm{~min}$. RT-PCR (Bio-Rad, USA) was performed using synthesized CDNA, forward/reverse primers, and SensiFAST SYBR Lo-Rox Kit (Bioline, England). The sequences of primers used in the experiment are presented in Table 2. The forward/reverse primer mixture $(2 \mu \mathrm{L}$ at $3 \mu \mathrm{M})$ was combined with $7.5 \mu \mathrm{L} \mathrm{SYBR}, 4.5 \mu \mathrm{L}$ DW, and $1 \mu \mathrm{L}$ cDNA. In addition, predenaturation was performed for 40 cycles at $5 \mathrm{~min}$ each at $95^{\circ} \mathrm{C}, 40$ cycles at $95^{\circ} \mathrm{C}$, and $1 \mathrm{~min}$ at $60^{\circ} \mathrm{C}$. The $\mathrm{Cq}$ values were calculated.

2.7. Immunocytochemistry. The cells were washed twice with PBS and fixed in 4\% paraformaldehyde for $15 \mathrm{~min}$ at room temperature. Then, the cells were permeabilized with $0.1 \%$ Triton X-100 in BSA buffer and blocked for $1 \mathrm{~h}$ at room temperature. Cells were incubated with primary antibodies diluted with $1 \%$ BSA for $2 \mathrm{~h}$ and then washed four times with $0.1 \%(\mathrm{v} / \mathrm{v})$ Tween-20 in PBS and incubated with Alexa Fluorconjugated secondary antibodies. The cells were imaged using a Zeiss LSM 760 confocal microscope with a C-Apochromat 20x objective lens $(\mathrm{NA}=1.40)$. PKR and pPKR primary antibodies were purchased from Santa Cruz Biotechnology; eIF $2 \alpha$ and peIF $2 \alpha$ antibodies were obtained from Cell Signaling Technology.

2.8. Statistical Analysis. Variables are expressed as mean\pm SEM. Unpaired one-tailed Student's $t$-tests were used to compare the data. Statistical significance was set at $p<0.05$.

\section{Results}

3.1. OC43 mRNA Expression. The OC43 mRNA expression was significantly higher in the OC43 group $(1.019 \pm 0.1413)$ than in the HGYGT group $(0.4205 \pm 0.07611)(p<0.05)$ (Table 3; Figure 1).

3.2. Cell Visualizing. Although the difference was not significant, the expression of PKR was higher in the cells treated with OC43 than cells treated with both OC43 and HGYGT. The expression of $\mathrm{pPKR}$ was significantly increased in the cells treated only with OC43 compared with the expression in cells treated with both OC43 and HGYGT. The expression of pPKR in the HGYGT group and uninfected A549 cells was not significantly different (Figure 2). The expression of peIF $2 \alpha$ was significantly higher in the control group than in the cells that were infected with OC43 and treated with HGYGT (Figures 3 and 4).

3.3. Cell Viability. The viabilities of cells treated with $100 \mu \mathrm{g} / \mathrm{mL}, \quad 200 \mu \mathrm{g} / \mathrm{mL}, \quad 300 \mu \mathrm{g} / \mathrm{mL}, \quad 400 \mu \mathrm{g} / \mathrm{mL}, \quad$ and $500 \mu \mathrm{g} / \mathrm{mL}$ HGYGT were $100.891 \%$, 97.4155\%, 98.3408\%, $100.627 \%$, and $103.914 \%$, respectively. There are no side effects in drug treatment (Figure 5).
3.4. $m R N A$ Expression. The expressions of interleukin-1 (IL-1), tumor necrosis factor- $\alpha$ (TNF- $\alpha$ ), cyclooxygenase-2 (COX-2), and nuclear factor kappa-light-chain-enhancer of activated $\mathrm{B}$ cells $(\mathrm{NF}-\kappa \mathrm{B})$ mRNA were significantly higher in the OC43 group than in the control group (Table 3; Figure 6). The expressions of IL-1 mRNA (OC43: $27.75 \pm 1.868$; HGYGT: $21.92 \pm 0.6333 ; p<0.05)$, TNF- $\alpha$ mRNA (OC43: 225.8 \pm 24.08 , HGYGT: $166.7 \pm 8.045$; $p<0.05$ ), COX-2 mRNA (OC43: $10.89 \pm 0.8811$; HGYGT: $8.609 \pm 0.3086 ; p<0.05$ ), and NF- $\kappa \mathrm{B}$ mRNA (OC43: $6.482 \pm 1.039$, HGYGT: $3.807 \pm 0.07861 ; p<0.05)$ were significantly higher in cell infected with OC43 than in cells that were infected with OC43 and treated HGYGT (Table 3; Figure 6).

The expressions of Interferon Alpha Inducible Protein 6 (IFI6), IFI44, IFI44L, IFI27, Interferon Regulatory Factor 7 (IRF7), 2'-5'-Oligoadenylate Synthetase Like (OASL), and ISG15 mRNA were significantly higher in the OC43 group than in the control group (Table 3, Figure 7). The expressions of IFI6 mRNA (OC43: 150.5 \pm 15.18; HGYGT: $84.61 \pm 7.541$; $p<0.01$ ), IFI44 mRNA (OC43: 1413 \pm 169.2 ; HGYGT: $761.7 \pm 49.3 ; p<0.05)$, IFI44L mRNA (OC43: 137.1 \pm 4.453 ; HGYGT: $98.37 \pm 2.426$; $p<0.001$ ), IFI27 mRNA (OC43: 506.2 \pm 48.8; HGYGT: $328 \pm 29.63 ; p<0.05)$, IRF7 mRNA (OC43: 7.599 \pm 0.6307; HGYGT: $5.222 \pm 0.7767 ; p<0.05$ ), OASL mRNA (OC43: $86.96 \pm 1.575$; HGYGT: $59.74 \pm 2.015$; $p<0.001$ ), and ISG15 mRNA (OC43: $71.27 \pm 4.874$; HGYGT: $48.62 \pm 4.098$; $p<0.05)$ were significantly higher in cells that were only infected with OC43 than in infected cells treated with HGYGT (Table 3, Figure 7).

The expressions of $\mathrm{I} \kappa \mathrm{B}$ kinase (IKK) and inducible nitric oxide synthase (iNOS) mRNA were significantly higher in the OC43 infected cells than in the control group (Table 3, Figure 8). The expressions of IKK mRNA (OC43: $2.6 \pm 0.0503$ HGYGT: $1.566 \pm 0.1109 ; p<0.0001)$ and iNOS mRNA (OC43: $2.195 \pm 0.05391$; HGYGT: $1.372 \pm 0.02985$; $p<0.0001)$ were significantly higher in the OC43-infected cells than in HGYGT-treated infected cells (Table 3, Figure 8).

\section{Discussion}

In December 2019, a number of pneumonia cases of unknown origin were diagnosed in Wuhan City, Hubei Province, China. From this pneumonia, a coronavirus with new genetic information, which has not yet been identified, was detected [5]. The World Health Organization named the virus SARS-CoV-2 as COVID-19 and declared a global pandemic [6]. From the beginning of the outbreak to March $23,2021,123,676,223$ patients were infected with the virus worldwide, and 2,722,912 patients died.

SARS-CoV-2 belongs to the Coronaviridae family, Betacoronavirus genus, and Sarbecovirus subgenus. Betacoronaviruses include $\mathrm{HCoV}-\mathrm{OC} 43, \mathrm{HCoV}-\mathrm{HKU} 1, \mathrm{SARS}-$ CoV-1, MERS-CoV, and SARS-CoV-2. The SARS-CoV-1 virus infected more than 8,000 people and killed 774 in Guangdong, China from 2002 to 2003 . The MERS-CoV virus infected 2,499 people and killed 861 in the Middle East from 2012 to $2019[7,8]$. 
TABle 2: Primer sequences used in RT-PCR.

\begin{tabular}{|c|c|c|}
\hline Target gene & Primer & Nucleic acid sequence \\
\hline OC43 & $\begin{array}{l}\text { Forward } \\
\text { Reverse }\end{array}$ & $\begin{array}{l}5^{\prime} \text {-AGC AAC CAG GCT GAT GTC AAT ACC-3 } \\
5^{\prime} \text {-AGC AGA CCT TCC TGA GCC TTC AAT-3 }\end{array}$ \\
\hline IL-1 & $\begin{array}{l}\text { Forward } \\
\text { Reverse }\end{array}$ & $\begin{array}{c}5^{\prime} \text {-CCA CAG ACC TTC CAG GAG AAT G-3' } \\
5^{\prime} \text {-GTG CAG TTC AGT GAT CGT ACA GG-3' }\end{array}$ \\
\hline TNF- $\alpha$ & $\begin{array}{l}\text { Forward } \\
\text { Reverse }\end{array}$ & $\begin{array}{c}\text { 5'-CTC TTC TGC CTG CTG CAC TTT G-3' } \\
5^{\prime} \text {-ATG GGC TAC AGG CTT GTC ACT C-3' }\end{array}$ \\
\hline COX-2 & $\begin{array}{l}\text { Forward } \\
\text { Reverse }\end{array}$ & $\begin{array}{c}5^{\prime} \text {-TCC AAA TGA GAT TGT GGG AAA ATT GCT- } 3^{\prime} \\
5^{\prime} \text {-AGA TCA TCT CTG CCT GAG TAT CTT-3' }\end{array}$ \\
\hline $\mathrm{NF}-\kappa \mathrm{B}$ & $\begin{array}{l}\text { Forward } \\
\text { Reverse }\end{array}$ & $\begin{array}{l}\text { 5'-GCA GCA CTA CTT CTT GAC CAC C-3' }^{\prime} \\
5^{\prime} \text {-TCT GCT CCT GAG CAT TGA CGT C-3 }\end{array}$ \\
\hline IFI6 & $\begin{array}{l}\text { Forward } \\
\text { Reverse }\end{array}$ & $\begin{array}{l}5^{\prime} \text {-TGC TAC CTG CTG CTC TTC AC-3' } \\
5^{\prime} \text {-CGA GCT CTC CGA GCA CTT TT-3' }\end{array}$ \\
\hline IFI44 & $\begin{array}{l}\text { Forward } \\
\text { Reverse }\end{array}$ & $\begin{array}{c}5^{\prime} \text {-CTG ATT ACA AAA GAA GAC ATG ACA GAC-3' } \\
5^{\prime} \text {-AGG CAA AAC CAA AGA CTC CA-3' }\end{array}$ \\
\hline IFI44L & $\begin{array}{l}\text { Forward } \\
\text { Reverse }\end{array}$ & $\begin{array}{l}\text { 5'-GTG GAT GAT TGC AGT GAG GTT-3' } \\
\text { 5'-AAT ATC CTT CAT GGG GTC CAG-3' }^{\prime}\end{array}$ \\
\hline IFI27 & $\begin{array}{l}\text { Forward } \\
\text { Reverse }\end{array}$ & $\begin{array}{l}5^{\prime} \text {-ATC AGC AGT GAC CAG TGT GG-3' } \\
5^{\prime} \text {-TGG CCA CAA CTC CTC CAA TC-3' }\end{array}$ \\
\hline IRF7 & $\begin{array}{l}\text { Forward } \\
\text { Reverse }\end{array}$ & $\begin{array}{c}5^{\prime}-\mathrm{CTG} \text { TGG ACA CCT GTG ACA CC-3' } \\
5^{\prime} \text {-TGC CCT CTC AGG AGC CAA-3' }\end{array}$ \\
\hline OASL & $\begin{array}{l}\text { Forward } \\
\text { Reverse }\end{array}$ & $\begin{array}{l}\text { 5'-GCG GAG CCC ATC ACG GTC AC-3' } \\
5^{\prime} \text {-AGG ACC ACC GCA GGC CTT GA-3' }\end{array}$ \\
\hline ISG15 & $\begin{array}{l}\text { Forward } \\
\text { Reverse }\end{array}$ & $\begin{array}{l}5^{\prime} \text {-CTC TGA GCA TCC TGG TGA GGA A-3' } \\
5^{\prime} \text {-AAG GTC AGC CAG AAC AGG TCG T-3' }\end{array}$ \\
\hline IKK & $\begin{array}{l}\text { Forward } \\
\text { Reverse }\end{array}$ & $\begin{array}{l}5^{\prime} \text {-CCA CCC AGT TCC ACA AGT CT-3' } \\
5^{\prime} \text {-CCT CCA CTG CGA ATA GCT TC-3' }\end{array}$ \\
\hline iNOS & $\begin{array}{l}\text { Forward } \\
\text { Reverse }\end{array}$ & $\begin{array}{c}5^{\prime} \text {-AGA CTG GAT TTG GCT GGT CCC TCC-3' } \\
5^{\prime} \text {-AGA ACT GAG GGT ACA TGC TGG AGC C-3' }\end{array}$ \\
\hline
\end{tabular}

SARS-CoV-2 is a positive-sense single-stranded RNA (ssRNA) virus, enclosed in an 80-220 nm envelope [9]. The virus recognizes a specific protein in the host cell membrane and binds to it, resulting in absorption by the cell. After the virus and the host cell are fused, the uncoated virus RNA invades the host cell. The RNA is replicated using host cell ribosomes and enzymes, and capsids are synthesized. Viruses formed by viral proteases are fused with the host cell membrane and released externally via budding (Figure 9). Antiviral drugs aim to phase out the life cycle of the virus to weaken or extinguish the invading virus by interfering with RNA transcription or inhibiting virus budding [10].

Clinical signs of COVID-19 typically begin within one week after infection and include persistent fever, cough, nasal congestion, fatigue, and other symptoms of upper respiratory infections. Symptoms of the gastrointestinal tract have also been reported, and some cases are asymptomatic [11]. Symptoms may progress to difficulty breathing or extreme chest pain related to pneumonia, decreased oxygen saturation, and physiological changes observed through imaging, such as chest X-ray or CT [12].

According to a study by Son et al. [13], 58.19\% of Korean medicine doctors use uninsured herbal extracts. Insured herbal extracts are widely prescribed due to the low cost to patients but differ from packaged herbal medications because they contain extracts of a single herb [14]. For this reason, uninsured herbal extracts, which are most similar to packed herbal medicines, are widely prescribed despite the cost burden of patients. In this study, uninsured herbal extracts were used for standardization and quality control of drugs.

HGYGT is listed in the Man-Byeong-Hoi-Chun of the Ming Dynasty, composed of 13 substances (Table 1). The HGYGT used in this study contains $0.5 \mathrm{~g}$ of Schizonepeta tenuifolia Briquet, Scutellaria baicalensis Georgi, Saposhnikovia divaricata Schischkin, Angelica gigas Nakai, Poncirus trifoliata, Rafinesque, Paeonia lactiflora Pallas, Glycyrrhiza uralensis Fischer, Cnidium officinale Makino, Gardenia jasminoides Ellis, Forsythia suspensa Vahl and $0.83 \mathrm{~g}$ of Angelica dahurica Bentham et Hooker f, Platycodon grandiflorum A. De Candolle, and Bupleurum falcatum Linné. HGYGT is widely used to treat otolaryngeal diseases, including otitis media [15]. Previous studies regarding HGYGT have reported a genotoxicity evaluation [16], antiallergic effects [17], anti-inflammatory effects through NF- $\kappa$ B activation control [18], antioxidant and anti-inflammatory effects through the reduction of iNOS and cytokine production [19], inhibition of inflammatory cell activation, and improvement of immune control [20].

$\mathrm{PKR}$, also known as eukaryotic translation initiation factor 2-alpha kinase 2 (EIF2AK2), is autophosphorylated by dsRNA in infected cells, leading to an immune response [21]. 
TABLE 3: mRNA expression.

\begin{tabular}{|c|c|c|c|}
\hline mRNA & Expression in control group & Expression in OC43 group ( $p$ value vs. control) & Expression in HGYGT group ( $p$ value vs. OC43) \\
\hline OC43 & & $1.019 \pm 0.1413$ & $\begin{array}{c}0.4205 \pm 0.07611 \\
* 0.0102\end{array}$ \\
\hline IL-1 & $1.002 \pm 0.04936$ & $\begin{array}{l}27.75 \pm 1.868 \\
* * * *<0.0001\end{array}$ & $\begin{array}{c}21.92 \pm 0.6333 \\
* 0.0209\end{array}$ \\
\hline TNF- $\alpha$ & $1.054 \pm 0.2352$ & $\begin{array}{c}225.8 \pm 24.08 \\
* * * 0.0004\end{array}$ & $\begin{array}{c}166.7 \pm 8.045 \\
* 0.0401\end{array}$ \\
\hline $\mathrm{COX}-2$ & $1.021 \pm 0.1516$ & $\begin{array}{c}10.89 \pm 0.8811 \\
* * * 0.0002 \\
\end{array}$ & $\begin{array}{c}8.609 \pm 0.3086 \\
* 0.0356\end{array}$ \\
\hline $\mathrm{NF}-\kappa \mathrm{B}$ & $1.009 \pm 0.09722$ & $\begin{array}{c}6.482 \pm 1.039 \\
{ }^{* *} 0.0032 \\
\end{array}$ & $\begin{array}{c}3.807 \pm 0.07861 \\
{ }^{*} 0.0311 \\
\end{array}$ \\
\hline IFI6 & $1.026 \pm 0.1712$ & $\begin{array}{c}150.5 \pm 15.18 \\
* * * 0.0003\end{array}$ & $\begin{array}{c}84.61 \pm 7.541 \\
{ }^{* *} 0.0089\end{array}$ \\
\hline IFI44 & $1.071 \pm 0.2847$ & $\begin{array}{c}1413 \pm 169.2 \\
* * * 0.0006\end{array}$ & $\begin{array}{c}761.7 \pm 49.3 \\
* 0.0105\end{array}$ \\
\hline IFI44L & $1.009 \pm 0.09376$ & $\begin{array}{l}137.1 \pm 4.453 \\
* * * *<0.0001\end{array}$ & $\begin{array}{c}98.37 \pm 2.426 \\
* * * 0.0008\end{array}$ \\
\hline IFI27 & $1.002 \pm 0.03935$ & $\begin{array}{c}506.2 \pm 48.8 \\
* * * 0.0002\end{array}$ & $\begin{array}{c}328 \pm 29.63 \\
* 0.0177\end{array}$ \\
\hline IRF7 & $1.009 \pm 0.09585$ & $\begin{array}{c}7.599 \pm 0.6307 \\
* * * 0.0002 \\
\end{array}$ & $\begin{array}{c}5.222 \pm 0.7767 \\
* 0.0382 \\
\end{array}$ \\
\hline OASL & $1.003 \pm 0.05799$ & $\begin{array}{l}86.96 \pm 1.575 \\
* * * * 00.0001\end{array}$ & $\begin{array}{c}59.74 \pm 2.015 \\
* * * 0.0002 \\
\end{array}$ \\
\hline ISG15 & $1.004 \pm 0.06054$ & $\begin{array}{l}71.27 \pm 4.874 \\
* * * *<0.0001 \\
\end{array}$ & $\begin{array}{c}48.62 \pm 4.098 \\
* 0.0118 \\
\end{array}$ \\
\hline IKK & $1.004 \pm 0.06449$ & $\begin{array}{l}2.6 \pm 0.0503 \\
* * * *<0.0001\end{array}$ & $\begin{array}{c}1.566 \pm 0.1109 \\
* * * *<0.0001\end{array}$ \\
\hline INOS & $1.002 \pm 0.04371$ & $\begin{array}{c}2.195 \pm 0.05391 \\
* * * *<0.0001\end{array}$ & $\begin{array}{c}1.372 \pm 0.02985 \\
* * * *<0.0001\end{array}$ \\
\hline
\end{tabular}

Values are presented as mean $\pm \operatorname{SEM}(n=3)\left({ }^{*} p<0.05 ;{ }^{* *} p<0.01 ;{ }^{* * *} p<0.001 ;{ }^{* * * *} p<0.0001\right)$.

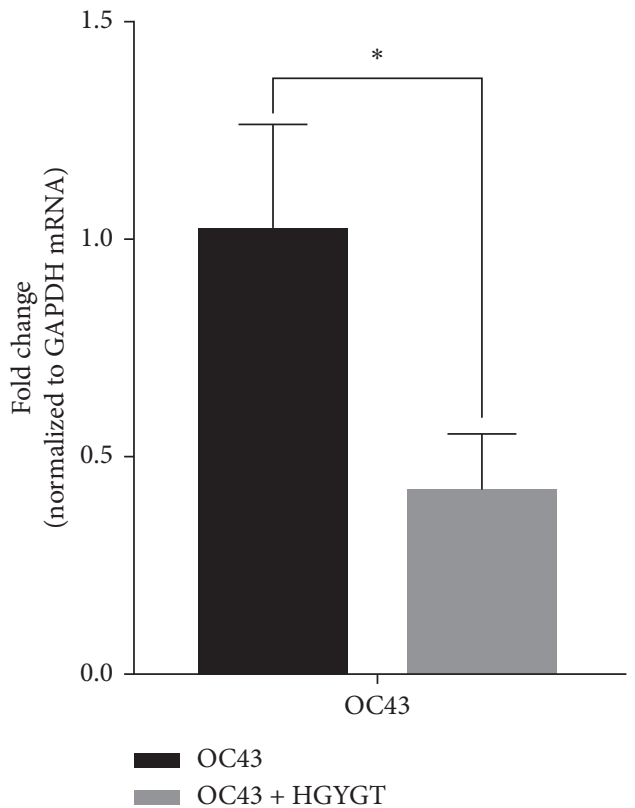

FIGURE 1: OC43 mRNA expression in A549 cells. mRNA expression is measured using quantitative real-time PCR and presented as mean \pm SD $(n=3)$. OC43: cells treated with OC43; OC43 + HGYGT: cells treated with OC43 and HGYGT $(100 \mu \mathrm{g} / \mathrm{mL})\left({ }^{*} p<0.05\right)$.
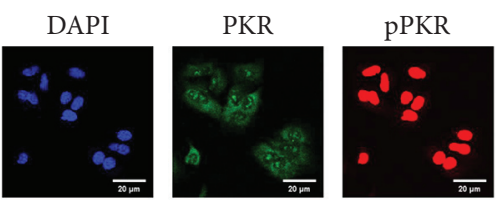

Merged

A549-WT
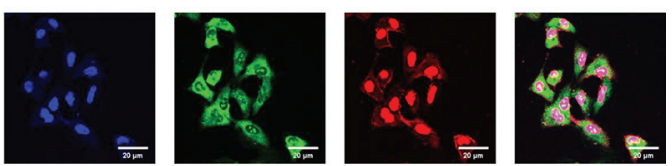

A549-OC43

+ Drug
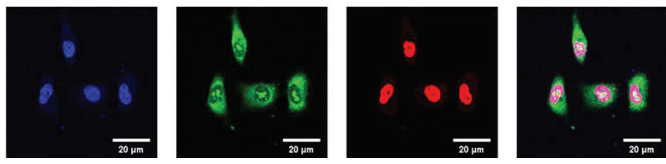

FIgURE 2: Visualization of PKR and pPKR expression. It used a Zeiss LSM 760 confocal microscope with a C-Apochromat 20x objective lens. Although the difference was not significant, the expression of PKR was increased in the "A549-OC43" than in the "A549-OC43 + drug." In the case of pPKR, the expression level was significantly increased in the "A549-OC43" than in the "A549OC43 + drug." There was no significant difference between the "A549-OC43 + drug" and the "A549-WT" (A549-WT: A549 cells with no treatment; A549-OC43: A549 cells treated with OC43; A549-OC43 + drug: A549 cells treated with OC43 and HGYGT). 


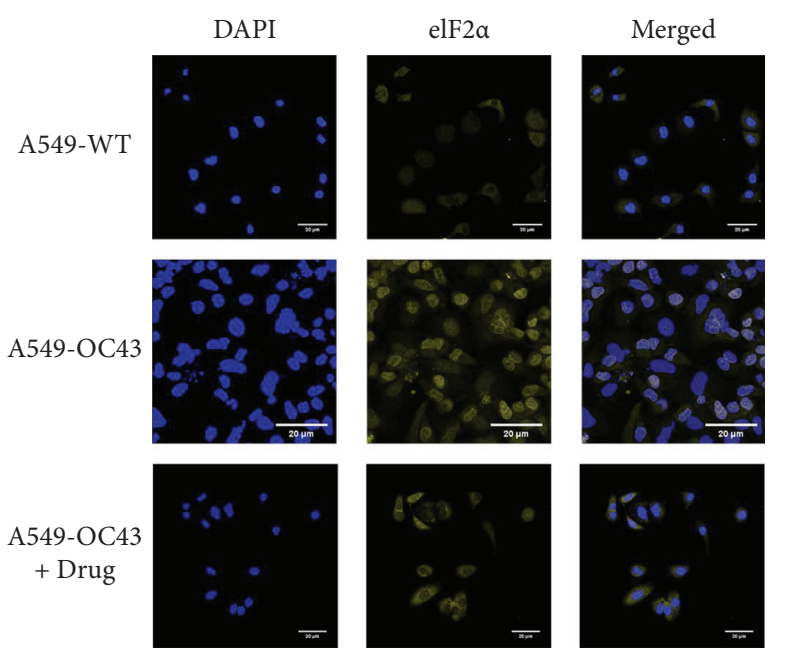

FIgURE 3: Visualization of eIF2 $\alpha$ expression. It used a Zeiss LSM 760 confocal microscope with a C-Apochromat 20x objective lens. The expression level of eIF $2 \alpha$ significantly increased in the "A549OC43" than in the "A549-OC43 + drug" (A549-WT: A549 cells with no treatment; A549-OC43: A549 cells treated with OC43; A549-OC43 + drug: A549 cells treated with OC43 and HGYGT).

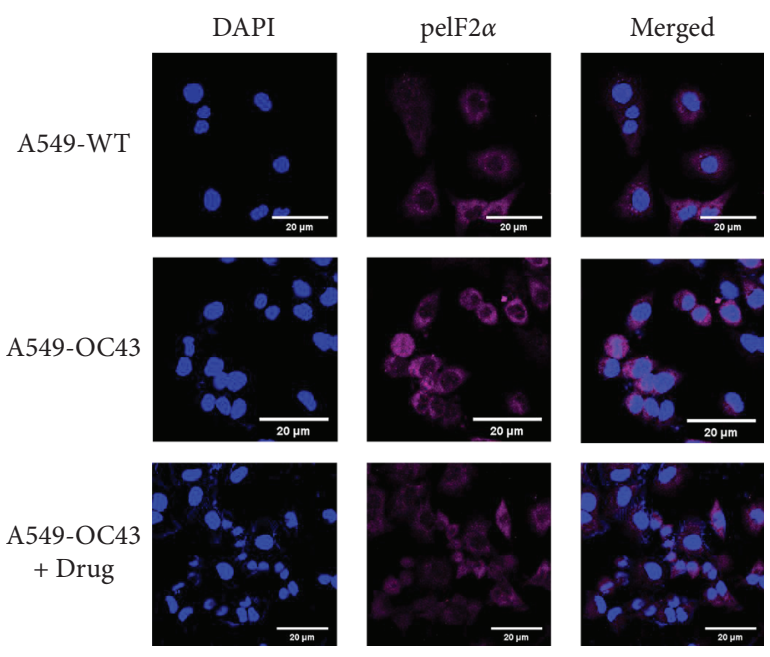

FIGURE 4: Visualization of peIF2 $\alpha$ expression. It used a Zeiss LSM 760 confocal microscope with a C-Apochromat 20x objective lens. The expression level of peIF $2 \alpha$ significantly increased in the "A549OC43" than in the "A549-OC43 + drug" (A549-WT: A549 cells with no treatment; A549-OC43: A549 cells treated with OC43; A549-OC43 + drug: A549 cells treated with OC43 and HGYGT).

pPKR is activated to inhibit global translation by preventing the transition of eIF2 to eIF2B [22]. Existing studies have reported that PKR is a signaling sensor for cellular metabolism [2]. The change in pPKR is proportional to the change in dsRNA. In this study, the expression of pPKR decreased as the amount of dsRNA decreased (Figure 2). Decrease of dsRNA expression inhibits the phosphorylation of PKR, thus inhibiting the activation of eIF $2 \alpha$. This reduces global translation and reduces protein synthesis (Figure 9). Recently, it has been reported that SARS-CoV-2 activates pPKR [23]. In this study, we found that HGYGT could block

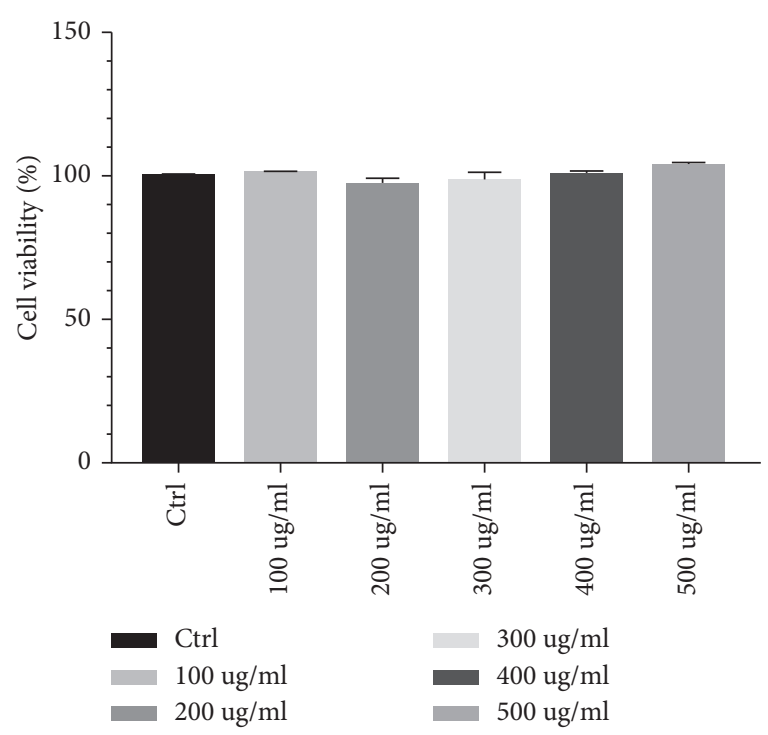

FIgURE 5: SRB assay of HGYGT in A549 cells. Cell viability was assessed by SRB assay at concentrations of $100 \mu \mathrm{g} / \mathrm{mL}, 200 \mu \mathrm{g} / \mathrm{mL}$, $300 \mu \mathrm{g} / \mathrm{mL}, 400 \mu \mathrm{g} / \mathrm{mL}$, and $500 \mu \mathrm{g} / \mathrm{mL}$. The results were calculated as a percentage for the control group and presented as mean \pm SEM.

phosphorylation of PKR with a decrease of virus RNA expression. This result signifies that HGYGT could be used as a drug to help treat COVID-19.

We confirmed that IFI6, IFI44, IFI44L, IFI27, IRF7, OASL, and ISG15 mRNA expressions were decreased in cells treated with HGYGT compared with those that were not treated with HGYGT (Figure 7). The reduced expressions of these proteins may affect the inactivation of type I interferon (IFN) pathway (Figure 9). Type 1 IFN pathway is a defense mechanism that induces an innate immune response, and excessive production of IFN- $\alpha / \beta$ can lead to the development of autoimmune diseases [24]. The reduction of ISGs that involved in type 1 IFN with HGYGT means that it could be used for the treatment of various immune and inflammatory diseases. Previous studies on hepatitis $\mathrm{C}$ virus and RNA viruses have reported that IFI44, IFI44L, and IRF7 are involved in translation [25]. In particular, IFI44L has been reported to be directly involved in the IFN response and acts as a regulator of antiviral responses [26]. It has been reported that IFI27 is involved in replication [27] and OASL is involved in translation [25] and replication [28].

SARS-CoV-2 promotes excessive ROS. As ROS increases, $\mathrm{H}_{2} \mathrm{O}_{2}$ accumulates in tissues. The increase in ROS level promotes viral replication and causes oxidative inflammation and cell apoptosis due to DNA damage. Recent studies have reported that catalase regulates cytokine in COVID-19, protects oxidative injuries, and inhibits replication of SARS-CoV-2 [29]. Viral infection increases free radicals, including nitrite oxide (NO), and depletes antioxidants [30]. RNA viruses cause oxidative stress, presumably due to the production of ROS in mitochondrial dysfunction, which occurs during virus infection with cells [31]. The production of iNOS involved in the oxidative injury involves activation of NF-kB/Rel [32]. Other studies have reported that inhibiting NF-kB pathways reduces iNOS 


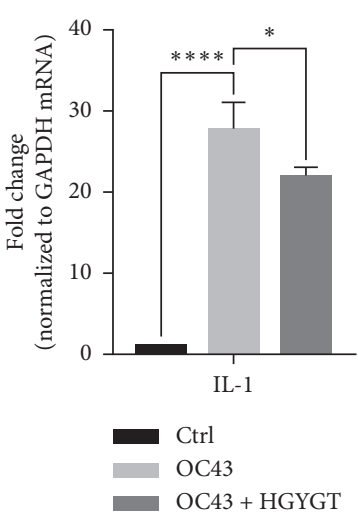

(a)

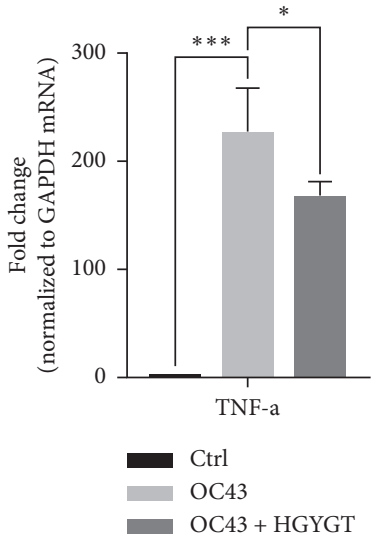

(b)

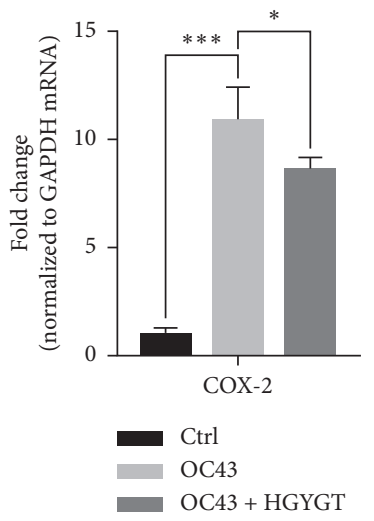

(c)

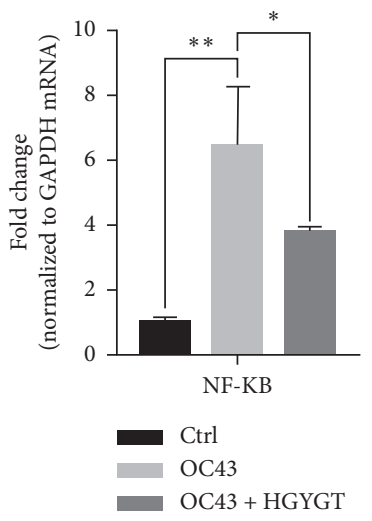

(d)

FIgURe 6: Proinflammatory cytokine mRNA expression in A549 cells. mRNA expression is measured using quantitative real-time PCR presented as mean \pm SD $(n=3)$. Ctrl: cells with no treatment; OC43: cells treated with OC43; OC43 + HGYGT: cells treated with OC43 and HGYGT $(100 \mu \mathrm{g} / \mathrm{mL})\left({ }^{*} p<0.05,{ }^{* *} p<0.01,{ }^{* * *} p<0.001,{ }^{* * * *} p<0.0001\right)$.

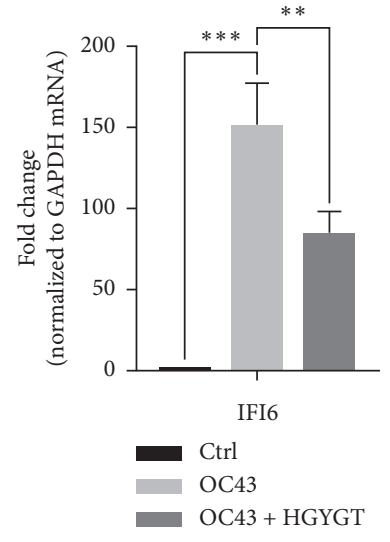

(a)

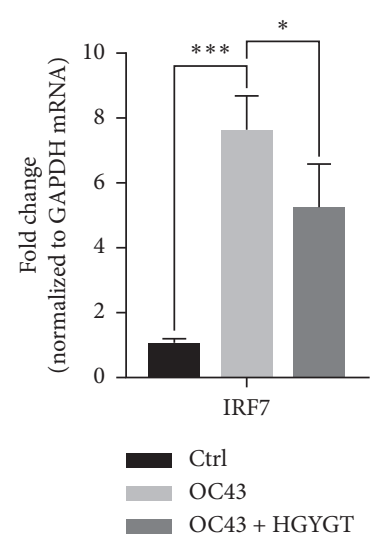

(e)

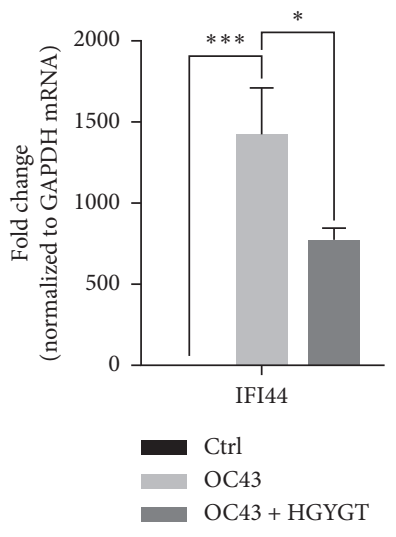

(b)

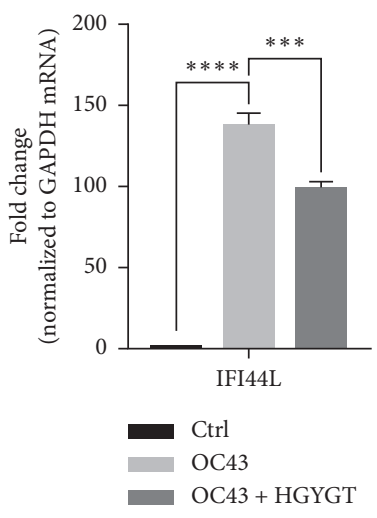

(c)

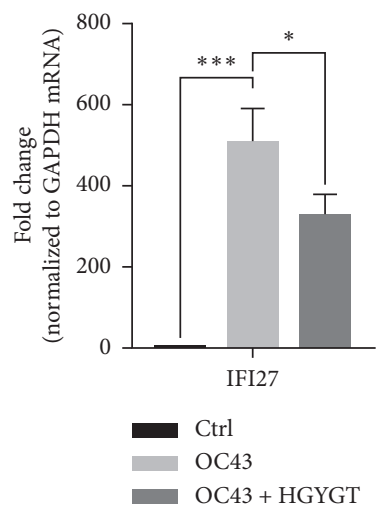

(d)

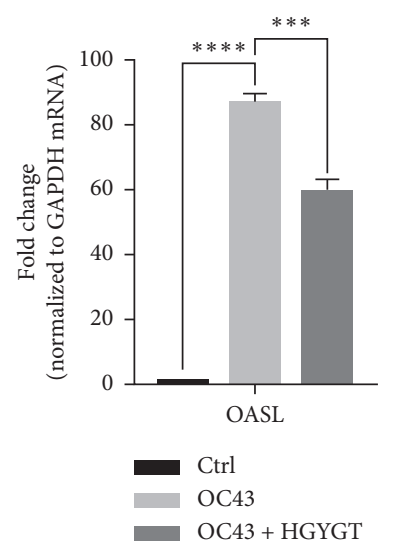

(f)

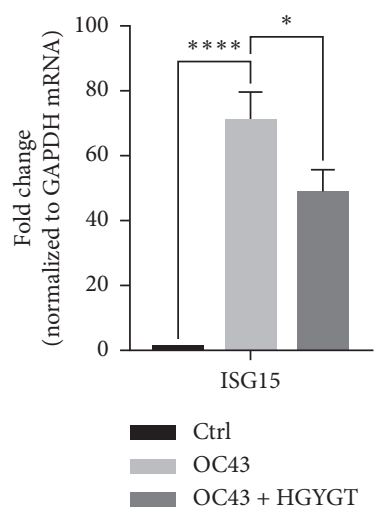

(g)

FIGURE 7: ISG mRNA expression in A549 cells. mRNA expression is measured using quantitative real-time PCR and presented as mean \pm S.D. $(n=3)$. Ctrl: cells with no treatment; OC43: cells treated with OC43; OC43 + HGYGT: cells treated with OC43 and HGYGT $(100 \mu \mathrm{g} / \mathrm{mL})\left({ }^{*} p<0.05 ;{ }^{* *} p<0.01 ;{ }^{* * *} p<0.001 ;{ }^{* * * *} p<0.0001\right)$.

mRNA and NO synthesis [33]. Both LPS and dsRNA are involved in type 1 IFN production. LPS and dsRNA activates antigen-presenting cells (APCs) via the Toll-like receptor 3
(TLR3) and TLR4 signaling pathway [34]. Previous studies have reported the effect of HGYGT suppressing production of iNOS by reducing NF-kB/Rel in an LPS-induced oxidative 


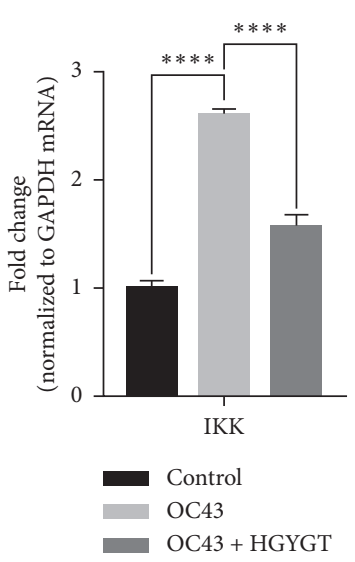

(a)

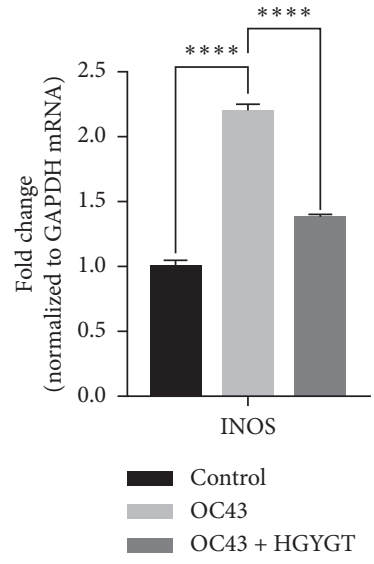

(b)

FIGURE 8: IKK and INOS mRNA expression in A549 cells. mRNA expression is measured using quantitative real-time PCR and presented as mean \pm SD $(n=3)$. Ctrl: cells with no treatment; OC43: cells treated with OC43; OC43 + HGYGT: cells treated with OC43 and HGYGT $(100 \mu \mathrm{g} / \mathrm{mL})\left({ }^{* * * *} p<0.001\right)$.

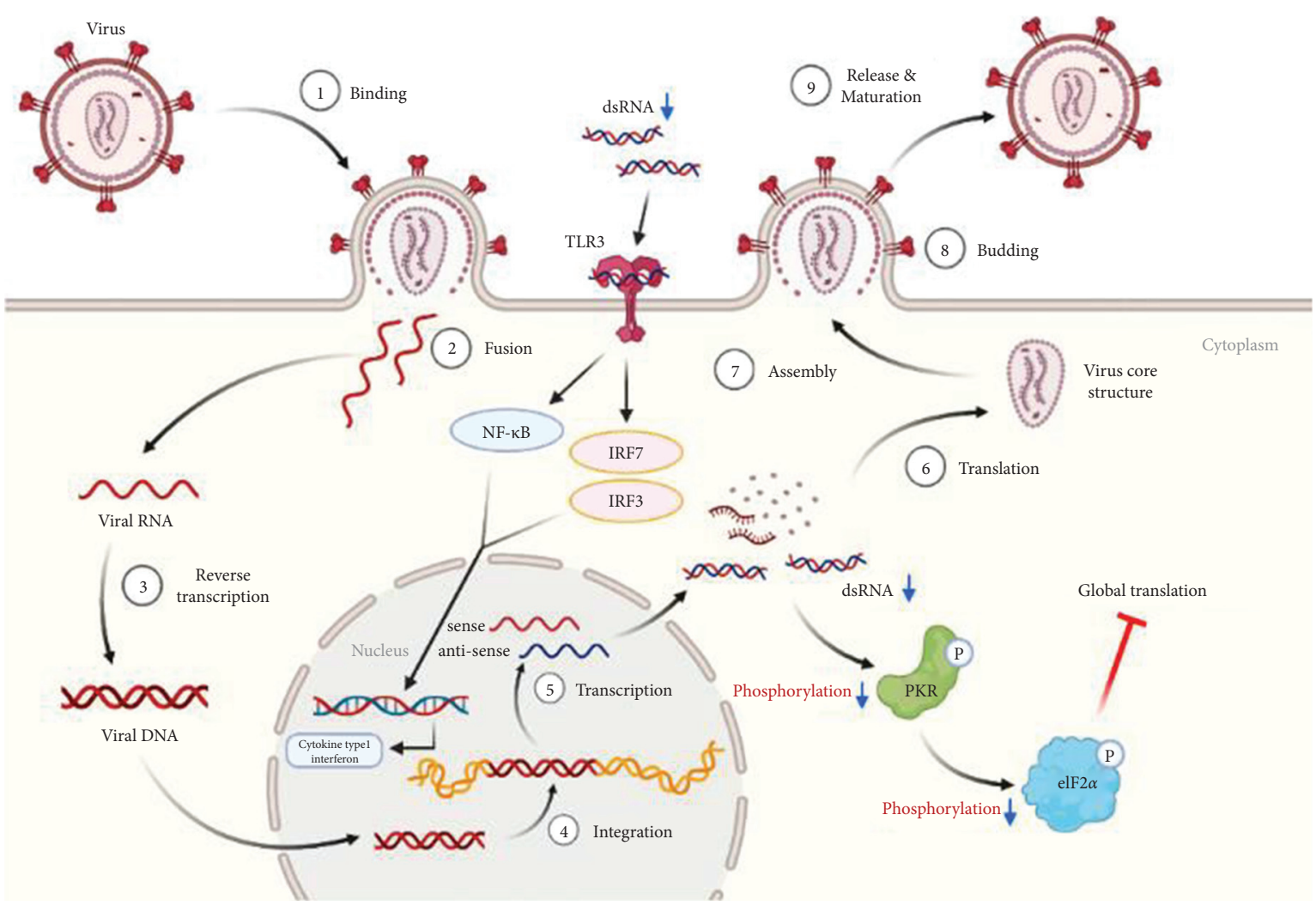

Figure 9: Antiviral effect of HGYGT on coronavirus (created with BioRender.com).

injury [35]. Inactivated NF-kB/Rel fails to induce transcription at the NF-kB/Rel bond site in the TATA box of iNOS gene [36]. The expression of iNOS, IKK, and NF- $\kappa \mathrm{B}$ was decreased in cells treated with HGYGT compared with those that were not treated with HGYGT (Figure 8). Inflammation with OC43 increases IKK and iNOS mRNA levels in OC43 group. HGYGT reduces IKK activity, and it appears that NF-kB/Rel is inactivated due to reduced $\mathrm{I} \kappa \mathrm{B}$ phosphorylation, resulting in iNOS expression reduction. The reduction of IKK and iNOS mRNA levels after HGYGT treatment is believed to be likely to reduce levels of dsRNA and replication of coronavirus by acting on $\mathrm{NF}-\mathrm{kB} / \mathrm{Rel}$ pathways to protect oxidative injury.

The results of this study suggest that HGYGT may have antiviral effects. We evaluated the expression of several proteins and mRNAs to determine the mechanism of 
HGYGT. HGYGT reduces the expression of mRNAs for cytokines, such as IL- 1, TNF- $\alpha$, COX-2, NF- $\kappa$ B, iNOS, and IKK, and the expressions of mRNAs for ISGs involved in the type I IFN pathway, resulting in a decreased immune response and fewer clinical symptoms. We suggest that HGYGT of uninsured herbal extracts manufactured by pharmaceutical companies effectively reduces the virus via regulation in NF-kB/Rel pathways and reduces the symptoms of the coronavirus infection. However, our study is limited due to its in vitro design and an insufficient sample size. More studies, including in vivo and clinical studies, are needed to determine the effects of HGYGT on coronavirus infections. The preprint of this manuscript [37] can be found in https://www.biorxiv.org/content/10.1101/2021.06.02. 446680v1.

\section{Conclusions}

HGYGT reduced the mRNA expression levels of coronavirus and inhibited the phosphorylation of PKR. It reduced mRNA expression level of iNOS and IKK. It means HGYGT may regulate $\mathrm{NF}-\mathrm{kB} /$ Rel pathways and has an antioxidative effect. HGYGT blocks a series of processes of ISG expression and reduces the inflammatory response in Betacoronavirusinfected A549 cells. Thus, HGYGT acts as a potential therapeutic agent for various clinical symptoms caused by coronavirus.

\section{Abbreviations}

APC: $\quad$ Antigen-presenting cells

COVID- Coronavirus disease 2019

19:

COX-2: Cyclooxygenase-2

dsRNA: Double-stranded RNA

eIF2: $\quad$ Eukaryotic initiation factor 2

EIF2AK2: Eukaryotic translation initiation factor 2-alpha kinase 2

HCoV: Human CoV

HGYGT: Hyeonggae Yeongyo-tang

IFI: Interferon alpha inducible protein

IFN: Interferon

IKK: $\quad$ I $\kappa$ B kinase

IL: $\quad$ Interleukin

iNOS: Inducible nitric oxide synthase

IRF: Interferon regulatory factor

ISGs: Interferon stimulated genes

MERS: Middle east respiratory syndrome

NF- $\kappa$ B: Nuclear factor kappa-light-chain-enhancer of activated B cells

NO: $\quad$ Nitrite oxide

OASL: $\quad 2^{\prime}-5^{\prime}$-Oligoadenylate synthetase-like

PKR: $\quad$ Protein kinase RNA-activated

ROS: $\quad$ Reactive oxygen species

RT: $\quad$ Reverse transcription

SARS- Severe acute respiratory syndrome coronavirus

CoV:

ssRNA: $\quad$ Single-stranded RNA

TLR: Toll-like receptor
TNF- $\alpha$ : Tumor necrosis factor- $\alpha$.

\section{Data Availability}

The datasets generated or analyzed in this study are available from the corresponding author upon reasonable request.

\section{Disclosure}

This paper has been submitted under the preprint [37] and can be found at https://www.biorxiv.org/content/10.1101/ 2021.06.02.446680v1.

\section{Conflicts of Interest}

The authors declare that there are no conflicts of interest regarding the publication of this article.

\section{Acknowledgments}

The authors are grateful to the experts for their valuable advice.

\section{References}

[1] O. J. McElvaney, N. L. McEvoy, O. F. McElvaney et al., "Characterization of the inflammatory response to severe COVID-19 illness," American Journal of Respiratory and Critical Care Medicine, vol. 202, no. 6, pp. 812-821, 2020.

[2] M. A. García, E. F. Meurs, and M. Esteban, "The dsRNA protein kinase PKR: virus and cell control," Biochimie, vol. 89, no. 6-7, pp. 799-811, 2007.

[3] S. J. Poynter and S. J. DeWitte-Orr, "Understanding viral dsRNA-mediated innate immune responses at the cellular level using a rainbow trout model," Frontiers in Immunology, vol. 9, p. 829, 2018.

[4] M. L. Reshi, Y. C. Su, and J. R. Hong, "RNA viruses: ROSmediated cell death," International Journal of Cell Biology, vol. 2014, Article ID 467452, 16 pages, 2014.

[5] D. Paraskevis, E. G. Kostaki, G. Magiorkinis, G. Panayiotakopoulos, G. Sourvinos, and S. Tsiodras, "Fullgenome evolutionary analysis of the novel corona virus (2019$\mathrm{nCoV}$ ) rejects the hypothesis of emergence as a result of a recent recombination event," Infection, Genetics and Evolution: Journal of Molecular Epidemiology and Evolutionary Genetics in Infectious Diseases, vol. 79, Article ID 104212, 2020.

[6] World Health Organization, WHO Director-General's Remarks at the Media Briefing on 2019- $n \mathrm{CoV}$ on 11 February 2020World Health Organization, Geneva, Switzerland, 2020.

[7] J. Guarner, "Three emerging coronaviruses in two decades," American Journal of Clinical Pathology, vol. 153, no. 4, pp. 420-421, 2020.

[8] T. T. Yao, J. D. Qian, W. Y. Zhu, Y. Wang, and G. Q. Wang, “A systematic review of lopinavir therapy for SARS coronavirus and MERS coronavirus-a possible reference for coronavirus disease-19 treatment option," Journal of Medical Virology, vol. 92, no. 6, pp. 556-563, 2020.

[9] J. A. Englund, Y. J. Kim, and K. McIntosh, "Human coronaviruses, including middle east respiratory syndrome coronavirus," in Feigin and Cherry's Textbook of Pediatric Infectious Disease, J. Cherry, G. J. Demmler Harrison, S. L. Kaplan, W. J. Steinbach, and P. J. Hotez, Eds., 
pp. 1846-1854, Elsevier, Philadelphia, PA, USA, 8th edition, 2019.

[10] J. M. Parks and J. C. Smith, "How to discover antiviral drugs quickly," New England Journal of Medicine, vol. 382, no. 23, pp. 2261-2264, 2020.

[11] W.-j. Guan, Z.-y. Ni, Y. Hu et al., "Clinical characteristics of coronavirus disease 2019 in China," New England Journal of Medicine, vol. 382, no. 18, pp. 1708-1720, 2020.

[12] T. P. Velavan and C. G. Meyer, "The COVID-19 epidemic," Tropical Medicine and International Health, vol. 25, no. 3, pp. 278-280, 2020.

[13] C. H. Son, Y. H. Kim, and S. Lim, "A study on Korean oriental medical doctors' use of uninsured herbal extracts and how to promote the insurance coverage of such herbal extracts," Korean Journal of Oriental Medicine, vol. 30, no. 4, pp. 64-78, 2009.

[14] S. J. Park, S. H. Kim, K. S. Kim et al., "A quantitative analysis of marker compounds in single herb extracts by the standard of KHP," The Korea Journal of Herbology, vol. 29, no. 3, pp. 35-42, 2014.

[15] M. R. Yang, K. S. Jin, H. J. Lee, M. W. Kwon, and E. J. Park, “A clinical study on the therapeutic effect of kamihyunggyeyungyotang for pediatric recurrent otitis media with effusion," Journal of Pediatrics of Korean Medicine, vol. 15, no. 2, pp. 87-100, 2001.

[16] S. Y. Jee, S. Y. Hwang, J. R. Lee, and S. C. Kim, "A study of genotoxicity test of hyeong-gae-yeon-gyo-tang extract," Korea Journal of Herbology, vol. 22, no. 4, pp. 287-300, 2007.

[17] T. S. Yoo, Y. S. Chin, and K. M. Jeong, "Study of the effects of Hyunggaeyeungyotang on the anti-allergic effect in rats and mice," The Journal of Pediatrics of Korean Medicine, vol. 4, no. 1, pp. 19-30, 1990.

[18] J.-H. Park and S.-U. Hong, "The effects of hyunggaeyungyotang of suppression of iNOS production on mice with allergic rhinitis," The Journal of Korean Oriental Medical Ophthalmology and Otolaryngology and Dermatology, vol. 25, no. 1, pp. 12-21, 2012.

[19] M. J. Kim, J. R. Lee, S. C. Kim, and S. Y. Jee, "Inhibitory effect of hyeonggaeyeongyo-tang water extract on production of nitric oxide, IL-6 and expression of iNOS, COX-2 in LPSactivated raw 264.7 cells," Korean Journal of Oriental Physiology \& Pathology, vol. 21, no. 2, pp. 491-497, 2007.

[20] R. Y. Kang, B. K. Park, S. B. Kim, H. J. Choi, and D. H. Kim, "The effects of HYT on various immunological factors related to pathogenesis of allergic dermatitis in NC/Nga mice induced by Biostir AD," Journal of Haehwa Medicine, vol. 18, no. 2, pp. 47-62, 2009.

[21] R. C. Patel, P. Stanton, N. M. McMillan, B. R. Williams, and G. C. Sen, "The interferon-inducible double-stranded RNAactivated protein kinase self-associates in vitro and in vivo," Proceedings of the National Academy of Sciences, vol. 92, no. 18, pp. 8283-8287, 1995.

[22] E. F. Meurs, Y. Watanabe, S. Kadereit et al., "Constitutive expression of human double-stranded RNA-activated p68 kinase in murine cells mediates phosphorylation of eukaryotic initiation factor 2 and partial resistance to encephalomyocarditis virus growth," Journal of Virology, vol. 66, no. 10, pp. 5805-5814, 1992.

[23] Y. Li, D. M. Renner, C. E. Comar et al., "SARS-CoV-2 induces double-stranded RNA-mediated innate immune responses in respiratory epithelial-derived cells and cardiomyocytes," Proceedings of the National Academy of Sciences, vol. 118, no. 6, Article ID e2022643118, 2021.
[24] J. Banchereau and V. Pascual, "Type I interferon in systemic lupus erythematosus and other autoimmune diseases," Immunity, vol. 25, no. 3, pp. 383-392, 2006.

[25] J. W. Schoggins, S. J. Wilson, M. Panis et al., "A diverse range of gene products are effectors of the type I interferon antiviral response," Nature, vol. 472, no. 7344, pp. 481-485, 2011.

[26] M. L. DeDiego, L. Martinez-Sobride, and D. J. Topham, "Novel functions of IFI44L as a feedback regulator of host antiviral responses," Journal of Virology, vol. 93, no. 21, 2019.

[27] Y. Itsui, N. Sakamoto, M. Kurosaki et al., "Expressional screening of interferon-stimulated genes for antiviral activity against hepatitis C virus replication," Journal of Viral Hepatitis, vol. 13, no. 10, pp. 690-700, 2006.

[28] M. Ishibashi, T. Wakita, and M. Esumi, " 2 ', $5^{\prime}$-Oligoadenylate synthetase-like gene highly induced by hepatitis $\mathrm{C}$ virus infection in human liver is inhibitory to viral replication in vitro," Biochemical and Biophysical Research Communications, vol. 392, no. 3, pp. 397-402, 2010.

[29] M. Qin, Z. Cao, J. Wen et al., "An antioxidant enzyme therapeutic for COVID-19," Advanced Materials, vol. 32, Article ID e2004901, 2020.

[30] F. C. Camini, C. C. da Silva Caetano, L. T. Almeida, and C. L. de Brito Magalhães, "Implications of oxidative stress on viral pathogenesis," Archives of Virology, vol. 162, no. 4, pp. 907-917, 2017.

[31] A. V. Ivanov, V. T. Valuev-Elliston, O. N. Ivanova et al., "Oxidative stress during HIV infection: mechanisms and consequences," Oxidative medicine and cellular longevity, vol. 2016, Article ID 8910396, 18 pages, 2016.

[32] Q. W. Xie, Y. Kashiwabara, and C. Nathan, "Role of transcription factor NF-kappa B/Rel in induction of nitric oxide synthase," Journal of Biological Chemistry, vol. 269, no. 7, pp. 4705-4708, 1994.

[33] M. Matsumura, H. Kakishita, M. Suzuki, N. Banba, and Y. Hattori, "Dexamethasone suppresses iNOS gene expression by inhibiting NF- $\kappa \mathrm{B}$ in vascular smooth muscle cells," Life Sciences, vol. 69, no. 9, pp. 1067-1077, 2001.

[34] K. Hoebe and B. Beutler, "LPS, dsRNA and the interferon bridge to adaptive immune responses: trif, Tram, and other TIR adaptor proteins," Journal of Endotoxin Research, vol. 10, no. 2, pp. 130-136, 2004.

[35] J. H. Park, J. C. Kim, and S. U. Hong, "The effects of Hyunggaeyungyo-tang of suppression of iNOS production on RAW 264.7 cell," The Journal of Korean Oriental Medical Ophthalmology \& Otolaryngology \& Dermatology, vol. 24, no. 1, pp. 78-85, 2011.

[36] C. J. Lowenstein, E. W. Alley, P. Raval et al., "Macrophage nitric oxide synthase gene: two upstream regions mediate induction by interferon gamma and lipopolysaccharide," Proceedings of the National Academy of Sciences, vol. 90, no. 20, pp. 9730-9734, 1993.

[37] S. Y. Won, I. C. Seol, H. R. Yoo, and Y. S. Kim, “Antiviral effect of hyunggaeyungyo-tang on A549 cells infected with human coronavirus," BioRxiv, 2021. 